\title{
AN INTERPRETIVE SYSTEMS VIEW OF KNOWLEDGE INVESTMENTS
}

\author{
TACO H. REUS \\ Erasmus University \\ ANNETTE L. RANFT \\ BRUCE T. LAMONT \\ Florida State University \\ GARRY L. ADAMS \\ Auburn University
}

\begin{abstract}
Viewing organizations as open, knowledge-dependent interpretation systems and building on the knowledge-based view, we develop a theoretical model of knowledge investments and value creation. By emphasizing the interpretive nature of organizations and examining knowledge requirements, capabilities, and investments, our contribution provides a more complete understanding of why some organizations make certain types of knowledge investments more than others and why these investments may have positive or negative effects on value creation.
\end{abstract}

The knowledge-based view of the firm has grown out of the resource-based tradition (e.g., Grant, 1996b) and has rapidly seized a dominant position among perspectives explaining variance in firm performance (Eisenhardt \& Santos, 2002). This perspective highlights that knowledge is the most strategically significant resource of the firm (Dierickx \& Cool, 1989; Gront, 1996a,b; Kogut \& Zander, 1992). In this research stream there is an implicit message that because knowledge is key to competitive advantage, "the more knowledge the better." That is, scholars often assume that the more managers invest in knowledge, the greater the benefits will be for their firms (Eisenhardt \& Santos, 2002).

Much knowledge-based research has focused on contexts where the effects of knowledge are drawn into high relief, such as managing in an international context (Kogut \& Zander, 1993) or in a technology-intensive environment (Ranft \& Lord, 2002). These contexts provide a solid base of initial support for the importance of knowledge for value creation. In particular, this research emphasizes the importance of knowl-

We owe many thanks to Aks Zaheer and the three anonymous reviewers, whose excellent suggestions and thoughtprovoking questions were invaluable in the development of the article. We are also very much indebted to Andac Arikan and Adelaide Wilcox King for their sharp comments. edge acquisition (obtaining external knowledge) and knowledge transfer (movement of existing, internal knowledge), along with the underlying practices that foster these knowledge capabilities. We define knowledge acquisition capabilities as a firm's ability to acquire external information or know-how and knowledge transfer capabilities as a firm's ability to transfer internal information or know-how.

Examples of investing in knowledge acquisition capabilities include investing in research and development to improve an organization's absorptive capacity (Cohen \& Levinthal, 1990) and hiring market experts to gain information and know-how about a foreign market to explore and exploit new market opportunities. Knowledge transfer calls for other practices, such as investing in improving communication across departments to develop an organization's combinative capability (Kogut \& Zander, 1992) or encouraging organization members to formiliarize themselves with knowledge domains of other members (Foss, 2003).

However, because research has focused on contexts where the effects of knowledge are clearly important, little theoretical insight has been gained into understanding the drivers of investing in knowledge across organizational contexts. Such insight is important because organizations differ in the contexts in which they

Copyright of the Academy of Management, all rights reserved. Contents may not be copied, emailed, posted to a listserv, or otherwise transmitted without the copyright holder's express written permission. Users may print, download, or email articles for individual use only. 
operate and the knowledge investments they make. For example, organizations vary widely in the extent of their investment in cross-border travel to facilitate cross-border knowledge transfer (Björkman, Barner-Rasmussen, \& Li, 2004), and in their extent of investment in knowledge management systems to encourage transferring knowledge across organizational subunits (Alavi \& Leidner, 2001). Similarly, organizations differ in the extent they invest in knowledge acquisition-for example, with respect to underscoring research and development (Cohen \& Levinthal, 1989). Yet it is unclear how knowledge requirements from organizational contexts systematically influence knowledge investments and the extent to which investments create value.

Some firms may underinvest in knowledgefor instance, when they invest in knowledge transfer within well-defined projects but neglect to invest in knowledge transfer across teams and projects (Brown \& Eisenhardt, 1997) or across organizational divisions (Lord \& Ranft, 2000). Nidumolu, Subramani, and Aldrich (2001) documented an example of underinvestment in knowledge transfer by a market research company. This firm relied on ad hoc knowledge transfer from veteran experts to new hires rather than investments in procedures and systems to facilitate knowledge transfer between veteran experts and new hires. The process through which a new hire sought out necessary knowledge from a veteran expert became so inefficient and idiosyncratic that it was termed buffalo chasing.

In other cases organizations seem to overinvest in knowledge. For example, firms may invest in knowledge simply by creating "makework" jobs. These jobs stress the importance of knowledge management without considering the value of that investment in light of specific knowledge requirements (cf. Brown \& Eisenhardt, 1997). Some firms make investments in knowledge management systems and knowledge codification that do not benefit firm performance. Haas and Hansen (2005) documented a case where a consulting firm developed significant document libraries and expert systems to transfer knowledge across project teams in the firm. In many cases, however, these investments did not enhance value because, for new project teams, face-to-face discussions were more valuable than expending time accessing informa- tion from the electronic systems (Haas \& Hansen, 2005).

A small but growing body of empirical evidence lends support for matching knowledge investment to more general environmental characteristics to ensure value creation (Haas \& Hansen, 2005; Miller \& Shamsie, 1996; Sabherwal \& Sabherwal, 2007). These studies provide initial support that the drivers of knowledge investments vary across firms, and they point out that investing in knowledge is not always better. However, despite initial empirical support, theory explaining the drivers and performance consequences of knowledge investments across organizational contexts is lacking (King \& Zeithoml, 2003).

We build on prior empirical work and the traditional position that knowledge creates value to develop theory clarifying why some organizations invest more than others in the acquisition and transfer of knowledge and why knowledge investments may or may not lead to value creation. We aim to explain the drivers and performance consequences of knowledge investments by developing a knowledge investments model that blends an interpretive systems view (Daft \& Weick, 1984) of organizations with the knowledge-based view (Gront, 1996b). Consistent with the knowledgebased view, the heart of our model builds on the idea that the primary role of firms is acquiring and transferring knowledge (Grant, 1996b; Kogut \& Zander, 1992). Consistent with the interpretive systems view, our model builds on the idea that firms are open systems that face knowledge requirements from their environment and tasks (Daft \& Weick, 1984). By combining these two perspectives, we develop our interpretive systems view of knowledge investments. This view highlights that gains or losses in value creation depend on making knowledge investments that address knowledge requirements.

While both the interpretive systems view and the knowledge-based view acknowledge limits on managers' ability to be fully rational in making knowledge investments, knowledge-based research has tended to overlook these limitations (Lane, Koka, \& Pathak, 2006). We base our explanations of both under- and overinvestment in the pursuit of knowledge on managers bounded rationality. Accordingly, some of our explanations are rooted in the path-dependent nature of knowledge investments, and others are based on interpretive schemes that discount or amplify managers' perceptions of knowledge 
requirements and the usefulness of investing in knowledge. As such, we also explain how knowledge investments affect value creation, both in a positive and a negative way.

In sum, the primary contribution of our theorizing is a more complete explanation of why some firms invest more in knowledge acquisition and transfer capabilities than others and how these investments relate to value creation. Given the long-touted benefits of knowledge investments in building competitive advantage (Grant, 1996b) and the growing anecdotal and empirical evidence that such investments may not always pay off (Haas \& Hansen, 2005; King \& Zeithaml, 2003), such theorizing helps integrate an array of seemingly disparate research on knowledge investments and offers a platform for future empirical research to isolate and verify the posited drivers and outcomes of knowledge investments.

\section{A KNOWLEDGE INVESTMENTS MODEL OF VALUE CREATION}

As a prelude to our development of a knowledge investments model, we clarify several assumptions driven by our intention to combine $a$ knowledge-based and an interpretive systems view of organizations. Our first set of assumptions, derived from the knowledge-based view, is that knowledge, in the form of both information and know-how, is potentially key to a firm's value creation. Information refers to facts and data that are standardized and can be understood and transmitted with limited cost (Kogut \& Zander, 1992; Winter, 1987). Know-how is action based, rooted in practice, dependent upon the practical skills or expertise that is difficult to articulate and codify, and accumulated over time through a learning process (Cook \& Brown, 1999; Polanyi, 1967; Zander \& Kogut, 1995).

Our second set of assumptions rests on the interpretive systems view that organizations are open systems that face knowledge requirements resulting from environmental uncertainty and equivocality and that these requirements vary across organizations and time (Daft \& Weick, 1984). Uncertainty refers to the lack of information to perform organizational tasks (Galbraith, 1973). Gaining more information will reduce that uncertainty. Equivocality refers to the existence of multiple and conflicting meanings about situations (Daft \& Lengel, 1986; Weick, 1969). Under conditions of equivocality, merely gaining more information may result in even more equivocality since it can create even more possible meanings. Rather, equivocality is resolved through developing know-how in order to facilitate judgment and sensemaking of possible meanings about a situation (Daft \& Lengel, 1986). Under either condition firms must resolve uncertainty and equivocality in order to function, and they do so by investing in knowledge. As interpretive systems, organizations must obtain data, give them meaning, and take appropriate actions (Daft \& Weick, 1984; Weick, 1979).

We assume that knowledge exists either within or outside a firm. As a result, when firms face knowledge requirements in the form of uncertainty or equivocality from environmental and task conditions, we expect them to invest in the acquisition and transfer of knowledge. Through these investments organizations not only use existing knowledge but also may create new knowledge to address knowledge requirements. For example, researchers, such as Nonaka (1994) and Wadhwa and Kotha (2006), have developed theories about knowledge creation through the interaction of organization members and through external venturing.

Further, our model assumes the presence of sufficient slack resources. Like any investment, knowledge investments require valuable resources. For example, acquiring and transferring knowledge requires promoting research and development (Cohen \& Levinthal, 1990), developing intensive communication (e.g., Ghoshal, Korine, \& Szulanski, 1994), and sustaining strong ties among senders and recipients of knowledge (Hansen, 1999). Firms with limited slack resources, or with resources in forms not amenable to redeployment in addressing knowledge requirements, may not be able to make knowledge investments, despite their being warranted.

We begin our discussion assuming full rationality. In doing so we clarify the knowledge investments firms would make if knowledge requirements were interpreted accurately. However, this assumption may be violated because decision makers may experience limitations in their ability to formulate and solve complex problems and in their ability to process information (Simon, 1957). Moreover, interpretations of knowledge requirements and appropriate investments are influenced by core organizational values and beliefs (Daft \& Weick, 1984), as institutionalized 
within organizations' interpretive schemes (Hinings \& Greenwood, 1988). The second half of the discussion emphasizes the causes and consequences of these limitations.

Taking these assumptions rooted in a combination of an interpretive systems view and a knowledge-based view, in the remainder of this paper we build a knowledge investments model as depicted in Figure 1. We first turn to the topic of organizational knowledge requirements.

\section{Knowledge Requirements}

As open systems, organizations face knowledge requirements from the tasks they perform and the environment with which they interact. These knowledge requirements are important to consider because they provide on answer to the question of why firms make certain types of knowledge investments more or less than others. The levels of uncertainty and equivocality firms face are important contributors to knowledge requirements from external and internal sources.

External sources of knowledge requirements. Knowledge-based researchers have emphasized the external environment in which firms face knowledge requirements (King \& Zeithaml, 2003). For example, Gront (1996a) points to the increasingly dynamically competitive environment as the main reason for the need for knowledge and a firm's ability to integrate knowledge. Specific characteristics of the external environment that influence knowledge requirements are usually not emphasized or fully explored in knowledge-based research. The interpretive systems assumptions underlying our knowledge investments model, however, indicate that environmental dimensions that affect uncertainty and equivocality should be particularly relevant to decision makers.

We consider two dimensions-environmental complexity and dynamism ${ }^{1}$-as important de-

\footnotetext{
${ }^{1}$ To simplify our presentation, we do not include environmental munificence or subdimensions of environmental dynamism in our model. Munificence refers to the availability of resources in the environment (March \& Simon, 1958). It is important since it may affect many things, such as organizational longevity, but recent research suggests it has limited direct effects on knowledge acquisition and transfer (Baker \& Nelson, 2005). Moreover, while the dynamism construct has recently been refined into subdimensions of velocity, unpredictability, and ambiguity (Davis, Eisenhardt, \& Bingham, 2008), these subdimensions yield predictions similar to those posited here. Therefore, as with our treatment of organizational task dimensions, our exposition is more accurately viewed as tapping a representative and parsimo-
}

FIGURE 1

A Model of Knowledge Investments

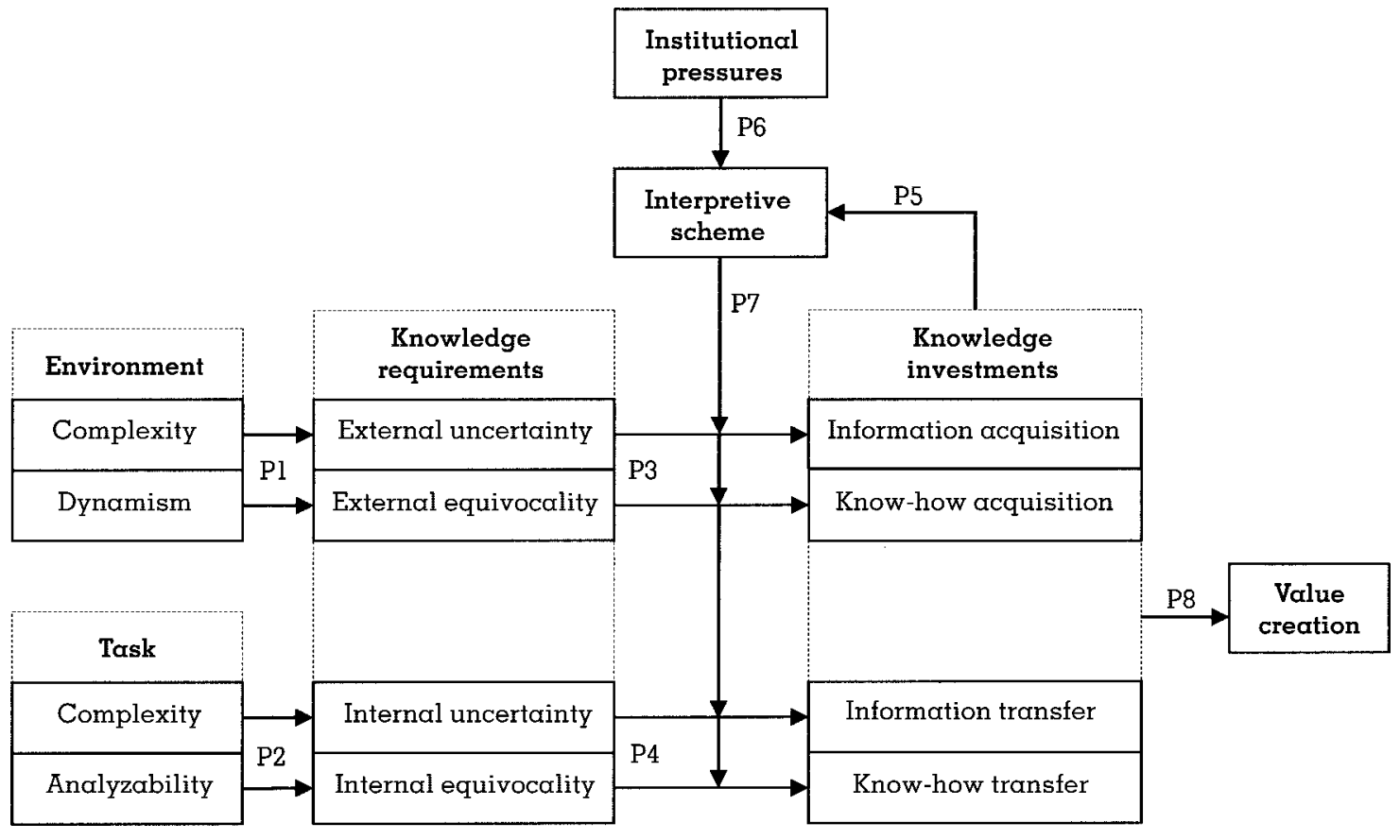


terminants of knowledge requirements. Environmental complexity refers to the number of elements in a firm's environment that need to be considered in decision making (Duncan, 1972). At one end of the dimension, a simple environment is characterized by few important elements that are quite similar to one another. Uncertainty is not great in this environment because information about the few elements that play a role is relatively easy to get. In contrast, at the other end of the dimension, a complex environment is characterized by many dissimilar yet related elements. Consequently, in a complex environment decision makers are more likely to lack information about certain elements. For example, expanding firms face increasing environmental complexity as their customer bases grow and they become dependent on more suppliers. As such, firms in complex environments have greater knowledge requirements in the form of a need to resolve uncertainty (Dess \& Beard, 1984). Therefore, we propose the following.

Proposition la: The greater the environmental complexity, the greater the knowledge requirements because of increased uncertainty.

Environmental dynamism refers to the pacing and magnitude of change in the external environment and its degree of predictability or ambiguity (Duncan, 1972). Dynamism also increases with the degree of interconnections among environmental elements (Aldrich, 1979). Whereas in stable environments change is limited or occurs slowly in a predictable manner, in dynamic environments change can come from anywhere, and triggers of change as well as consequences are more difficult to interpret. In dynamic environments organization members may have multiple, ambiguous interpretations about the best way to face their environment. For example, industries that are characterized by intense demand instability, such as the motion picture industry, commonly show ambiguity about means-end linkages that call for interpretation from experts, whereas other more stable industries, such as the gold and silver ore industries, have relatively clear means-end linkages

nious set of environmental dimensions, emphasizing those that affect information and know-how needs.
(Hambrick \& Abrahamson, 1995). Firms in transition economies commonly face equivocality because a wide variety of changes require interpretation of both new ways of conducting business and a changing competitive landscape (Kriauciunas \& Kale, 2006). Consequently, whereas complexity calls for resolving uncertainty, dynamism requires resolving the equivocality organization members face.

Proposition 1b: The greater the environmental dynamism, the greater the knowledge requirements because of increased equivocality.

Internal sources of knowledge requirements. From a knowledge-based view, an organization can be seen as a bundle of information and know-how, which needs to be coordinated in order to complete tasks (Hayek, 1945). Organizational tasks are the specific processes that a firm performs to produce its products or deliver its services. Complex tasks are characterized by a number of subtasks not easily separated into independent parts (March \& Simon, 1958). A task becomes more complex as the sheer number of distinguishing subtasks increases and as more connections among these subtasks exist (March \& Simon, 1958; Thompson, 1967). Task complexity increases uncertainty among organization members because it increases the number of people and units in various parts of the organization requiring effective coordination and communication of information in order to complete a task (Galbraith, 1973; Thompson, 1967). For example, software development firms include technical software engineers and customer interface groups (Ranft \& Lord, 2002). Technical software engineers often specialize further and work on subcomponents of an overall software system; customer interface groups inform software engineers of necessary features to serve customer needs. This specialization and technological sophistication results in a complex system of interrelated yet fairly distinct task components (Ranft \& Lord, 2002). Decision makers in firms characterized by such interdependent complex tasks face more uncertainty.

Proposition 2a: The greater the task complexity, the greater the knowledge requirements because of increased uncertainty. 
Similarly, tasks vary in the degree to which organization members face equivocality. Task analyzability is reflected in the extent to which tasks can be managed by a clear set of procedures as opposed to requiring sophisticated judgment (Perrow, 1967). Analyzable tasks are unequivocal. With clear means-ends connections, little is subject to interpretation, and standardized routines can be easily applied (Daft \& Weick, 1984). When tasks are analyzable, individuals can follow specific procedures to resolve problems.

In contrast, when analyzability is low, tasks are difficult to understand, and multiple interpretations of the task composition and appropriate outcomes may exist (King \& Ranft, 2001; Nonaka, 1994). Less analyzable organizational tasks are subject to causal ambiguity with respect to their performance implications. While such causal ambiguity may make the tasks more difficult to imitate by competitors, it also forms a constraint on task execution because it taxes organization members, requiring higherlevel cognitive efforts to resolve equivocality (King \& Zeithaml, 2001). For example, multinational companies can achieve competitive advantage from exploiting the combination of resources from foreign subsidiaries (Gupta \& Govindarajan, 2000), but lower analyzability of such organizational tasks as a result of cultural differences between subsidiaries and unique resource path dependencies makes them susceptible to multiple interpretations. Therefore, task analyzability affects the equivocality decision makers face.

Proposition 2b: The lower the task analyzability, the greater the knowledge requirements because of increased equivocality.

\section{Knowledge Investments Under Conditions of Full Rationality}

Based on our previous discussion, decision makers consider their tasks and environment, interpret the uncertainty and equivocality they face, and, consequently, determine what resources to invest in and what actions to take (Daft \& Weick, 1984; Thomas, Clark, \& Gioia, 1993). Uncertainty and equivocality have very different consequences for both the type and magnitude of knowledge investments firms make (summarized in Table 1). To specify the drivers of investments rooted in knowledge requirements, we turn to a discussion of two general types of knowledge capabilities in which firms may invest: knowledge acquisition and knowledge transfer. Knowledge acquisition capabilities refer to a firm's ability to acquire external knowledge (information or know-how), whereas knowledge transfer capabilities refer to a firm's ability to transfer internal knowledge (information or know-how).

Knowledge investments to resolve external knowledge requirements. Simply put, the greater the environmental uncertainty, the greater the need for information (Galbraith, 1973, 1977; March \& Simon, 1958; Thompson, 1967) and the larger the knowledge investments needed to optimize information acquisition. Environmental complexity that influences the need to resolve external sources of uncertainty can be dealt with through investing in activities that foster the acquisition of information about external sources. For example, firms with many different types of customers may face uncertainty about the manner in which to approach customers and about which unique needs to fulfill. To resolve such uncertainty, firms need to acquire information by investing in market research, databases of customer characteristics, or systems that facilitate collecting such information.

Raff (2000) documented this in his study of Border's. As Border's grew, the book superstore invested in and continuously upgraded its information systems in order to acquire detailed data on its customers and to make that information available to sellers and buyers. As Border's customer base expanded, the firm invested in increasingly sophisticated inventory software that allowed it to "incorporate increasingly subtle decision support information and increasingly subtle characteristics of what individual books ... were like" (Raff, 2000: 1046). Similarly, Kim, Umanath, and Kim (2006) explain that firms in supply chains may invest in electronic databases to acquire information from supply chain partners in response to demand uncertainty.

Proposition 3a: The greater the environmental uncertainty, the more organizational decision makers will invest in information acquisition.

Unlike uncertainty, equivocality cannot be resolved by acquiring more information. In fact, 
TABLE 1

Knowledge Requirements As Triggers of Knowledge Investments

\begin{tabular}{|c|c|c|c|}
\hline Requirements & Capabilities & Investments & Exemplars \\
\hline External uncertainty & $\begin{array}{l}\text { Information } \\
\text { acquisition }\end{array}$ & $\begin{array}{l}\text { Investments in information } \\
\text { retrieval systems, } \\
\text { databases }\end{array}$ & $\begin{array}{l}\text { Firms in supply chains that invest in electronic } \\
\text { databases to acquire information from } \\
\text { supply chain partners in response to demand } \\
\text { uncertainty (Kim, Umanath, \& Kim, 2006) } \\
\text { Book superstores that invest in information } \\
\text { retrieval systems to collect customer data } \\
\text { (Raff, 2000) }\end{array}$ \\
\hline External equivocality & $\begin{array}{l}\text { Know-how } \\
\text { acquisition }\end{array}$ & $\begin{array}{l}\text { Investments in absorptive } \\
\text { capacity, research and } \\
\text { development, attracting } \\
\text { experts in the field, } \\
\text { acquisition of centers of } \\
\text { expertise, learning } \\
\text { alliances }\end{array}$ & $\begin{array}{l}\text { Firms in transition economies that invest in the } \\
\text { acquisition of operating know-how from } \\
\text { distant sources to reflect the new demands } \\
\text { of their changing environment (Kriauciunas } \\
\text { \& Kale, 2006) } \\
\text { Pharmaceutical companies that make } \\
\text { investments to gain access to biotech know- } \\
\text { how in response to a turbulent environment } \\
\text { (Schweizer, 2005) } \\
\text { MNCs that make knowledge-seeking } \\
\text { investments in foreign affiliates with highly } \\
\text { skilled employees (Nachum \& Zaheer, 2005) }\end{array}$ \\
\hline Internal uncertainty & $\begin{array}{l}\text { Information } \\
\text { transfer }\end{array}$ & $\begin{array}{l}\text { Investments in information } \\
\text { and communication } \\
\text { systems, common access } \\
\text { databases }\end{array}$ & $\begin{array}{l}\text { Hospitals that invest in clinical information } \\
\text { systems for the collection and access of } \\
\text { patient records (Lapointe \& Rivard, 2007) } \\
\text { IT organizations that document task } \\
\text { responsibilities in a database to reduce } \\
\text { search time for "who knows what and } \\
\text { where" (Vaast \& Levina, 2006) }\end{array}$ \\
\hline Internal equivocality & $\begin{array}{l}\text { Know-how } \\
\text { transfer }\end{array}$ & $\begin{array}{l}\text { Investments in combinative } \\
\text { capability, face-to-face } \\
\text { meetings, management } \\
\text { transfer, key employee } \\
\text { transfer, integrative } \\
\text { teams }\end{array}$ & $\begin{array}{l}\text { Acquirers that invest in cross-border visits to } \\
\text { transfer technological know-how to newly } \\
\text { acquired foreign units (Bresman, Birkinshaw, } \\
\text { \& Nobel, 1999) } \\
\text { Multinational companies that invest in rich } \\
\text { transmission channels among subsidiaries to } \\
\text { transfer know-how among subsidiaries } \\
\text { (Gupta \& Govindarajan, 2000) }\end{array}$ \\
\hline
\end{tabular}

accumulating more information might actually increase the potential for conflicting interpretations and contribute to increasing equivocality (Daft \& Lengel, 1986). Rather, equivocality can be resolved through acquiring richer know-how about a situation in order to make sense of it (Weick, 1995). Know-how facilitates judgment and helps firms select the best among conflicting interpretations. Thus, while uncertainty requires more information, equivocality requires know-how (Daft \& Lengel, 1986; Daft \& Weick, 1984). And, as interpretive systems, firms that perceive equivocality will make knowledge investments to attempt to resolve this.

When the environment is dynamic, to make sense of the continuously changing nature of conducting business, firms need to acquire new know-how about the environment (Cohen \&
Levinthal, 1989; Grant, 1996a; Lane et al., 2006). Because of the time-intensive, path-dependent nature of developing know-how internally, some of this know-how acquisition may occur by making transactions in the market (Dierickx \& Cool, 1989; Zollo \& Winter, 2002). For example, Brown and Eisenhardt (1997) describe how successful firms in the highly dynamic computer industry hired marketing futurists and technology gurus to make sense of the fast-changing environment and to probe into the future. Alternatively, a firm may pursue know-how through alliances or acquisitions (Coff, 1999; Hamel, 1991; Inkpen \& Dinur, 1998; Lane et al., 2006). Ranft and Lord (2002) describe an acquisition of a small biotech firm specializing in combinatorial chemistry drug screening techniques. This acquisition allowed a large pharmaceutical 
firm to immediately obtain the know-how to screen multiple chemical compounds for potential commercial use at an exponential rate compared to traditional pharmaceutical screening methods. Consequently, for some firms, investing in processes that facilitate effective hiring, acquisitions, or alliances to acquire know-how is critical.

Alternatively, in response to external sources of equivocality, firms acquire know-how by building this capability internally (Cohen \& Levinthal, 1990; Jansen, Van den Bosch, \& Volberda, 2005). Firms may make initial investments into research and development, labs, people, and equipment with the intent that, over time, know-how will be built (Ahuja, Coff, \& Lee, 2005). This type of development builds on the path-dependent nature of dynamic capabilities in an organizational context with sustained investment over time to develop absorptive capacity. With absorptive capacity, organization members better recognize the value of new, external knowledge; assimilate this knowledge; and may apply it to commercial ends (Cohen \& Levinthal, 1990).

Because the level of equivocality organizational decision makers experience varies across environments, investments in know-how acquisition will likely vary as well. For example, some firms are more willing to invest in developing absorptive capacity because they perceive a need for learning in the environment (Cohen \& Levinthal, 1989). Pharmaceutical companies may make more knowledge investments to gain access to know-how in response to a turbulent environment caused by the increasing influence of biotechnology over the industry (Schweizer, 2005). Or a changing global environment may lead certain firms in transition economies to invest in the acquisition of operating know-how from distant sources in the West (Kriauciunas \& Kale, 2006), while MNCs may make knowledgeseeking investments into foreign affiliates with highly skilled employees (Nachum \& Zaheer, 2005). Know-how acquisition, then, is pursued under conditions of equivocality through a variety of means, and, in general, we expect the following.

Proposition 3b: The greater the environmental equivocality, the more organizational decision makers will invest in know-how acquisition.
Knowledge investments to resolve internal knowledge requirements. Tasks can be a source of uncertainty when complexity requires interconnections between people and units. For example, some diversified financial institutions face the task of coordinating activities among different banking institutions, as well as between banking and insurance divisions, which creates considerable uncertainty between units and people. Firms can resolve such uncertainty by investing in intricate information or communication systems and databases that facilitate the transfer of information (Galbraith, 1977). Alternatively, firms can invest in common access databases, which deal with internal sources of uncertainty through coordinating and standardizing activities as well as facilitating communication (Argyris, 1999). For example, a hospital may invest in clinical information systems for the collection and access of patient records (Lapointe \& Rivard, 2007), or an IT organization may invest in a database that documents task responsibilities to facilitate the search for who knows what and where (Vaast \& Levina, 2006). As interpretive systems, organizations will determine their internal sources of uncertainty and interpret the types of investments in information systems needed to deal with these knowledge requirements.

Proposition 4a: The greater the task uncertainty, the more organizational decision makers will invest in information transfer.

Alternatively, decision makers will assess internal sources of equivocality and determine their firms' knowledge investments. Through transferring know-how, organizations and groups of organization members can combine and recombine knowledge in order to deal with task equivocality (Argote, 1999). While the presence of absorptive capacity facilitates the ability both to recognize the value of related external knowledge and to use it for commercial purposes (Cohen \& Levinthal, 1990), investments in the development of combinative capability are necessary to foster know-how transfer.

Combinative capability refers to the capacity "to generate new applications from existing knowledge" (Kogut \& Zander, 1993: 391). The development of combinative capability depends on the ability of a firm to create a social community that is rooted in action (Brown \& Duguid, 
1991; Cook \& Brown, 1999; Kogut \& Zander, 1992). Firms can achieve this by investing in internal social networks through organizing meetings, conducting training programs, transferring managers and specialists across subsidiaries, investing in coffee bars with the explicit purpose of encouraging informal connections and problem solving among product developers, or investing in activities that facilitate the development of a general atmosphere that stimulates knowledge combination and promotes the diffusion of know-how (Brown \& Eisenhardt, 1997; Jansen et al., 2005; Kogut \& Zander, 1992). Thus, emerging needs to resolve internal sources of equivocality trigger investments in know-how transfer.

Proposition 4b: The greater the task equivocality, the more organizational decision makers will invest in knowhow transfer.

\section{Knowledge Investments Under Conditions of Bounded Rationality}

The preceding propositions rest on an interpretive systems view that firms face knowledge requirements in the form of uncertainty and equivocality and that decision makers will respond to make knowledge investments in capabilities that address this uncertainty and equivocality. We have assumed that decision makers are fully rational in their efforts to interpret these knowledge requirements and in their selection of knowledge investments. In practice, however, this assumption of full rationality is often violated (Cyert \& March, 1963; Perrow, 1984; Spender, 2003; Todorova \& Durisin, 2007).

Critical limitations to objective assessment of knowledge requirements occur because sources of uncertainty and equivocality are identified and interpreted by decision makers through core organizational values and beliefs (Daft \& Weick, 1984), as institutionalized within an organization's interpretative scheme (Hinings \& Greenwood, 1988). Hinings and Greenwood (1988) described an interpretive scheme as capturing the core ideas, values, and beliefs reflected in and reproduced by organizations' existing structures and systems. Interpretive schemes shape decision makers' perceptions of knowledge requirements, the value of knowledge investments, and the acceptable forms of investments (Hinings \& Greenwood, 1988; Todorova \& Durisin, 2007). Therefore, here we view interpretive schemes as important filters of knowledge requirements, the adequacy of the available information and know-how in meeting those needs, the appropriate types and levels of knowledge investments, and the merits of these investments made in knowledge-dependent interpretive systems.

Belief structures about knowledge investments embodied in interpretive schemes can come from an organization's distinctive institutionalized character (Selznick, 1984), heavily conditioned by its own history (Amis, Slack, \& Hinings, 2004; Weick, 1995). Therefore, even for firms facing similar knowledge requirements, interpretive schemes act as a filter of the perceptions of knowledge requirements, the value of available information and know-how, and the value of knowledge investments due to the differences between firms in their history-conditioned institutionalized beliefs and practices.

Partly, a firm's interpretive scheme is developed through prior knowledge investments. Knowledge investments lead to knowledge output, which, in turn, can influence a firm's interpretive scheme (cf. Lane et al., 2006). Organizational capabilities are said to have a distinct life cycle of development (Helfat \& Peteraf, 2003). In the early stages of capability development, investment has a greater impact on generating the unique nature of the capability (Ahuja \& Katila, 2004). For example, through related investments in acquiring knowledge, absorptive capacity begets more absorptive capacity (Zahra \& George, 2002). As the capability matures, however, investment has a sustaining and refining effect rather than a developing effect (Helfat \& Peteraf, 2003). While this process enriches the development of some capabilities, it also may norrow the range of investments to develop a limited set of knowledge capabilities (Leonard-Barton, 1992) and makes it increasingly difficult to modify investment strategies to acquire or transfer knowledge from alternative areas. Similarly, investments in building strong ties among organization members over time may constrain the acquisition of new knowledge by narrowing the firm's search processes (Gavetti \& Levinthal, 2000). Because systems, structures, cultures, people, and processes are, to some degree, inert, and because redirecting knowledge investments may be difficult, prior 
investments influence the interpretive scheme used by organizational decision makers. As such, some decision makers may not identify the need to make changes in investments, or, even when they do recognize the need for capability change, forces within the firm may prevent action (Gilbert, 2005; Levinthal \& March, 1993).

Several researchers (e.g., Foss, 2003; Kjærgaard \& Kautz, 2008) have recounted the history of Oticon, the world's largest hearing aid company, which illustrates the tenacity of interpretive schemes. In the early 1990s Oticon became known as a prototypical "spaghetti organization," which involved a flat structure that heavily emphasized knowledge sharing through competence centers. Organization members at the operational level constantly invested time and resources into developing new knowledge management initiatives, and they stressed the importance of such investments. By the late 1990s, top management identified considerable costs involved with the spaghetti organization and became more hesitant to support knowledge management initiatives (Kjærgaard \& Kautz, 2008). However, organization members kept investing time and resources to introduce new ideas, proposals, and experiments with information systems solutions, even after previous projects were not supported.

Thus, prior knowledge investments affect not only what organizations are good at but, from an interpretive systems perspective, what decision makers come to believe their firms are, or need to be, good at. We state this in a formal proposition.

Proposition 5: Prior knowledge investments shape interpretive schemes of organizational decision makers to favor similar knowledge investments.

It is too simplistic to view values about knowledge investments as idiosyncratic to each organization, however. Belief structures about knowledge investments embodied in interpretive schemes come not only from an organization's distinctive institutionalized character and prior knowledge investments but also from external institutional pressures that have a homogenizing effect on belief structures about knowledge investments across organizations in the same industry or organizational field. Knowledge investments occur in a social context where accepted practices are likely to be mimicked by others (DiMaggio \& Powell, 1983; Meyer \& Rowan, 1977). That is, decision makers conform to social conventions of what is considered effective management to gain legitimacy (DiMaggio \& Powell, 1983).

External institutional pressures may lead to overly optimistic belief structures and misdirected investments in knowledge resources. For example, since the 1990s, knowledge management has gained immense popularity in the academic and popular press. Popular bestsellers such as Senge's (1990) The Fifth Discipline have emphasized the importance of making knowledge investments, and success stories of knowledge management systems used by consulting firms such as Accenture and Ernst \& Young have further fueled this interest in making knowledge investments. These popularized ideas of knowledge management likely have instilled institutionalized beliefs and practices that boost new knowledge investments, regardless of any gaps between knowledge requirements and available information and know-how in at least some, and possibly many, firms (cf. Abrahamson \& Fombrun, 1994).

Institutional pressures underlying legitimacy can endanger firms because they make it difficult for decision makers to see other, potentially better, alternatives to business practices. Ultimately, the process of institutionalization may lead to a single dominant view that is widely held across firms (McKinley, Zhao, \& Rust, 2000). An illustration of such a practice can be seen in the airline industry. For several years many airlines invested in developing and utilizing a massive data and reservation system, citing competitive disadvantage for those airlines not having access to the centralized system. Yet the airline with the highest and most consistent profitability in the industry did not participate in the centralized reservation system at all (Freiberg \& Freiberg, 1996). The airline industry saw few exceptions to institutional pressures and industry norms, driven by idiosyncratic, distinctive history-dependent values in some organizations. We expect the homogenizing effects of institutional pressures on belief structures embodied in interpretive schemes to account for many of the observed similarities in the valued knowledge investments across organizations in industries, such as the airline industry. 
Proposition 6: The more external institutional pressures emphasize certain types of knowledge investments, the more these types of knowledge investments are valued in the interpretive schemes of organizational decision makers.

Thus, prior knowledge investments and external institutional pressures shape the interpretive schemes of organizational decision makers. These interpretive schemes, in turn, will likely influence and distort the extent to which perceived knowledge requirements lead to knowledge investments. Interpretive schemes may lead to overinvestment or misapplied investments in favored knowledge capabilities, regardless of any rational assessment of the gaps between knowledge requirements and capabilities. Norms and beliefs about knowledge investments shared among decision makers may emphasize the benefits of making certain investments in knowledge and may ignore or downplay the associated costs. For example, in a study of management consulting firms, Haas and Hansen (2005) illustrated that the organizational emphasis on investing in knowledgesharing systems and communications could, in fact, be detrimental to the success of obtaining new consulting projects. They explained that these missteps might occur because team members feel "obliged to go through the motions of consulting all the available knowledge sources because of formal incentives to utilize such resources, as well as an informal but pervasive norm of knowledge sharing in the firm" (Haas \& Hansen, 2005: 19).

Interpretive schemes may also lead to underinvestment in knowledge resources-in general or in specific areas. Perhaps because of early failed attempts to acquire or transfer knowledge, some interpretive schemes may emphasize the costs or barriers to effective knowledge investments or to particular types of knowledge investments, while downplaying their potential benefits. Or it may be that innovative investments of any kind, such as those associated with knowledge, may be inconsistent with interpretive schemes that emphasize efficiency over innovation (cf. Rosner, 1968). Since knowledge investments raise costs and may cause temporary inefficiencies, decision makers who are more efficiency oriented may discourage, delay, or avoid making such knowledge investments. Regardless of the source of the values and beliefs about knowledge investments embodied in an interpretative scheme, these values will systematically affect the actual knowledge investments made by decision makers.

Proposition 7: Interpretive schemes moderate the extent to which knowledge requirements lead to knowledge investments such that (a) interpretive schemes where knowledge investments are highly valued will amplify these types of knowledge investments, regardless of knowledge requirements, and (b) interpretive schemes where knowledge investments are not valued will depress these types of knowledge investments, regardless of knowledge requirements.

\section{IMPLICATIONS FOR VALUE CREATION}

The preceding propositions explain that variations in knowledge investments among organizations are rooted in knowledge requirements and in the interpretations of these requirements. The interpretive systems view of knowledge investments also has implications for value creation. Firms can reap benefits from knowledge investments when the investments resolve uncertainty and equivocality. When uncertainty or equivocality is not adequately addressed by organizational decision makers, firms cannot function effectively and value will be destroyed. For illustrative purposes, as depicted in Figure 2 , we can conceptualize four qualitatively different conditions, based on different ways in which knowledge investments and requirements are matched or mismatched, each with rather differ-

FIGURE 2

Four Knowledge Investment Conditions

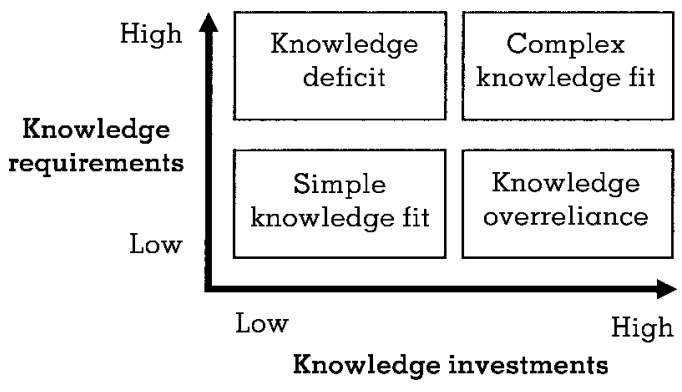


ent antecedents, costs, and performance outcomes. We label these conditions simple knowledge fit, complex knowledge fit, knowledge deficit, and knowledge overreliance.

Simple knowledge fit occurs when organizations make few knowledge investments when facing limited knowledge requirements. An organization in a stable and simple environment with tasks that show few interdependencies among organization members can reap the greatest benefits from relatively limited knowledge investments. In this context the greatest benefits from knowledge capabilities stem from investments in relatively simple infrastructures. Such firms should focus on making nonknowledge investments, such as investments in land, equipment, and facilities, which may accrue market power or market size, rather than information and know-how (cf. Miller \& Shamsie, 1996). Simple fit situations are characterized by low costs associated with knowledge investments and positive returns from nonknowledge investments.

The relationship between knowledge investments and value creation is particularly strong when knowledge requirements are high. The need for information and the need for know-how become more important when organizations face more uncertainty and equivocality (Daft \& Lengel, 1986; Galbraith, 1977). Organizations that show a complex knowledge fit match high knowledge requirements with requisite knowledge investments. Considering our discussion of knowledge requirements, such complex knowledge fit can take a variety of forms, depending on the knowledge requirements organizations face. For example, when firms face a complex and dynamic environment, it becomes more important for them to acquire the information and know-how to be innovative, develop new products, and shorten project completion times (Hansen, 1999; Hoopes \& Postrel, 1999). Under these conditions it is important for firms to make considerable investments in information systems and in developing absorptive capacity so as to excel in information and know-how acquisition. Bearing long-run costs associated with knowledge investments is acceptable because improving knowledge acquisition capabilities creates the important benefits of resolving the external uncertainty and equivocality encountered in complex and dynamic environments (Cohen \& Levinthal, 1989).
Complex knowledge fit also is indicative of organizations that invest in information and know-how transfer when they face internal uncertainty and equivocality. For example, a geographically dispersed organization that performs tasks that are difficult to analyze and highly interdependent can reach a complex knowledge fit when decision makers invest in the development of strong information sharing systems and combinative capabilities through intricate networks of organization members and subunits (Ghoshal \& Bartlett, 1990; Kogut \& Zander, 1993). Similarly, there is a complex knowledge fit when firms are able to develop strong ties and to use rich communication media during the implementation of high-technology acquisitions that are characterized by considerable internal equivocality (Ranft \& Lord, 2002).

Organizational decision makers who do not make investments in knowledge acquisition or transfer while their organizations face knowledge requirements fall prey to conditions of knowledge deficit. In this underinvestment situation the costs associated with knowledge investments may be low, but the opportunity costs result in a subpar performance situation. The consequences of this condition have been the focus of much conceptual and empirical research. Several studies have emphasized organizations that show a lack of investments in know-how transfer when there is a high need to resolve internal equivocality-for example, Szulanski's (1996) findings indicate that the transfer of best practices is likely to be hindered severely when decision makers do not invest in developing the relationships between knowledge senders and recipients. Or, when firms face equivocality, they may invest in codification to facilitate information acquisition and transfer but neglect to invest in acquiring and transferring know-how to be able to interpret necessary adaptations to prior solutions. Haas and Hansen (2005) have shown that this can be particularly harmful in highly competitive environments that call for unique interpretations to foster differentiation from competition.

The knowledge investments model of value creation proposed here suggests that it is the organizational decision makers' interpretive schemes that deter knowledge investments, despite their importance as dictated by the knowledge requirements the decision makers' organi- 
zations face. A knowledge deficit situation may be rooted in reducing costs of investments in existing capabilities (King \& Tucci, 2002). Rather than investing in new capabilities with greater or less well-known costs, organizations may choose to reinvest in readily available capabilities. While the costs associated with developing existing capabilities may be reduced over time (Zahra \& George, 2002), the increasingly narrow concentration can create significant opportunity costs associated with new capabilities. Similarly, prior knowledge investments in serving existing customer groups con prevent firms from noticing knowledge requirements associated with new customer segments (Todorova \& Durisin, 2007). Such organizations face a knowledge deficit when changing knowledge requirements call for investments in novel knowledge capabilities.

Some decision makers, because of their organizations' interpretive schemes, will make significant knowledge investments even though their organizations do not face the requisite knowledge requirements. An organization that finds itself in a knowledge overreliance state overinvests capital, personnel, and time in managing knowledge relative to knowledge requirements. Such overinvestments may stem from institutionally embedded interpretive schemes valuing investing in knowledge capabilities for their own sake, without clear goals for efficiency or effectiveness. Other overinvestments may be caused by the path-dependent nature of the competency-building process itself.

Decision makers who overinvest in building knowledge capabilities face opportunity costs in the form of foregone opportunities to invest in alternative options, such as building a new plant or reducing debt. In addition, knowledge overreliance may be consequential because considerable costs can be associated with knowledge investments. Teece (1977) conducted a rare direct test of costs associated with managing knowledge. He referred to resource costs of knowledge transfer as those costs related to transmission and absorption of know-how. In a study of international transfers of technological know-how, he found that these resource costs made up a considerable portion of the total project costs, ranging from 2.25 percent to 59 percent, with a mean of 19.16 percent. More recent research has emphasized less direct costs of investing in knowledge and has shown that investments in research and development or information systems may result in unexpected costs associated with insider trading (Ahuja et al., 2005), information overload for decision makers (Hansen \& Haas, 2001), or inappropriate use of information (Haas \& Hansen, 2005). Despite Teece's early work, research examining the relative benefits and costs of knowledge investment is in its very early stages. However, Haas and Hansen (2005) have provided initial evidence that there may be knowledge overreliance situations in which costs outweigh benefits of knowledge investments.

Some organizations may simultaneously fall into a knowledge deficit situation in one knowledge domain while being overreliant in another knowledge domain. Partly, such a situation is reflected in March's (1991) description of organizations that do not balance their exploration and exploitation of knowledge. For example, under conditions of decreasing external equivocality and increasing internal equivocality, decision makers may invest too much in developing the capability to acquire know-how and too little in the capability to transfer know-how within the organization. Such organizations are at once prone to knowledge deficit and knowledge overreliance and are likely to face opportunity costs associated with a lack of know-how transfer, while at the same time facing redundant costs associated with know-how acquisition. Levitt and March's (1988) discussion of competency traps also suggests simultaneous knowledge overreliance and knowledge deficit. Organizational decision makers who invest in the development of a competency and keep making investments to improve and exploit it may become overly reliant on this competency and unable to reap benefits from other more valuable opportunities that may emerge for which new knowledge capabilities are necessary.

Nag, Corley, and Gioia (2007) offer an example of a firm that can be classified in this situation. They describe the story of Tekmar (a pseudonym), a high-tech organization that attempted to transform from a pure research and development organization into a market-oriented organization by "grafting" new, nontechnological knowledge. This transformation created a sudden increase in knowledge requirements in the form of external equivocality of the market and a diminution in knowledge requirements of internal equivocality that characterized the pure 
research and development work. While top management identified the new knowledge requirements the organization faced, organization members persisted in viewing the firm as a pure research and development company and discounted the new need to invest in acquiring market knowledge.

Kor and Leblebici (2005) also describe such a situation when they explain how partners of several law firms used associates to leverage their expertise to deal with the knowledge requirements the firms faced. Some law firms invested in developing information acquisition and transfer capabilities through lateral hiring. While this helped the firms build knowledge bases and helped them grow, excessive use of partner leveraging and lateral hiring of associates made it impossible for partners to effectively coach associates, making it more difficult to respond to new and increasing demands of internal and external equivocality. As a result, the law firms could not effectively acquire and transfer the necessary know-how to develop a competitive advantage, and value was destroyed.

Thus, knowledge matches lead to value creation, while mismatches lead to value destruction. Under simple knowledge fit conditions, firms that face limited uncertainty and equivocality create value when they make nonknowledge investments. Firms that are characterized by complex knowledge fit situations create value when they face knowledge requirements (external/internal uncertainty/equivocality) that are matched by requisite knowledge investments (acquisition/transfer of information/knowhow). Under knowledge deficit conditions, organizations face opportunity costs, because a lack of investments limits the ability to resolve equivocality or uncertainty. Finally, knowledge overreliance conditions indicate large investments in developing knowledge capabilities that do not match a firm's knowledge requirements; these knowledge investments then may only function as redundant costs, such as the direct costs related to know-how transmission and absorption stressed by Teece (1977) or the indirect costs associated with insider trading, information overload, and inappropriate use of information stressed in previous research.

Proposition 8: The extent to which knowledge investments lead to value creation is positively related to the extent to which they match knowledge requirements.

\section{DISCUSSION}

Our purpose in this paper was to blend an interpretive systems view with the knowledgebased view of the firm in order to develop a more complete understanding of why some organizations make certain types of knowledge investments more than others and why those investments may have both positive and negative effects on value creation. In doing so we developed a model of knowledge investments grounded in a knowledge-dependent, interpretive systems view of organizations. Our model identifies important drivers of knowledge investments, details the interpretive nature of assessing knowledge requirements and building knowledge capabilities, and examines the implications for value creation. In the end, we hope we have both offered a useful way of understanding why some firms invest more in knowledge than others and highlighted the difficulties in having these knowledge investments lead to value creation.

Our theorizing places existing research in $a$ more complete framework for understanding the development of knowledge capabilities. Most of the research to date has focused on how knowledge investments do and do not lead to knowledge capabilities (e.g., Hoopes \& Postrel, 1999; Szulanski, 1996), or it has clarified the benefits of knowledge capabilities for value creation (e.g., Gront, 1996b; Kogut \& Zander, 1992). Our model helps to show that knowledge investments are motivated by a complex mix of environmental and task factors interpreted by organizational decision makers. Not all firms will want or need to invest in knowledge capabilities equally. Nor is it likely that firms will benefit equally from their knowledge investments. In fact, given the range of factors that filter managers' assessments of knowledge requirements and the utility of various knowledge investments, it is unrealistic to expect that even the most omniscient of decision makers will make optimal knowledge investments that consistently improve value creation.

The model developed here also helps to explain performance results observed in prior research. As Miller and Shamsie (1996) docu- 
mented, our theorizing predicts very different performance benefits of knowledge investments in industries where knowledge requirements are extremely high and low. Similarly, Haas and Hansen's (2005) findings documenting the costs of knowledge investments and their dysfunctional performance effects are consistent with the predictions of our model. The costs of knowledge investments, including the opportunity costs, con get very high for firms, particularly in contexts that provide little need for these knowledge investments. The model also further clarifies the performance outcomes of knowledge investments by predicting different types of matches and mismatches with knowledge requirements.

By identifying several variables and relationships currently underrepresented in the literature, we also offer a roadmap for future theorizing and empirical research on knowledge capabilities. Clearly, to balance the benefits of knowledge investments, future research will need to explicitly consider the costs. As knowledge investments become a greater part of overall investments, firms face increasingly more direct and indirect costs associated with these investments (Jacobson \& Prusak, 2006; Teece, 1977). Future research that can identify different types of costs associated with knowledge investments will be important to further understand the consequences of knowledge deficit and knowledge overreliance situations.

Also, drivers of knowledge investments would benefit from empirical testing. For example, it may be useful for future research to document the relative frequency of interpretive schemes having amplifying, as opposed to dampening, effects on knowledge investments and how the processes may be different at various levels or types of gaps between knowledge requirements and current capabilities. The importance of matching knowledge investments with requirements may depend on the particular sources of uncertainty and equivocality.

Apart from interpretive schemes, there may be other important factors that distort knowledge investments. A particularly relevant factor here might be the organizational politics through which powerful decision makers manipulate and control important information channels (Argote, McEvily, \& Reagans, 2003). For example, Pettigrew (1973) described how a manager restricted information flows to other managers and the board of directors. Even when organizations make knowledge investments, managers' self-interest may prevent optimization of these investments (cf. Haas, 2006). When decision makers do share a common interest in organizational value creation, they might differ in how they perceive they can reach this value creation-for example, because of the position they hold in the organization (Cyert \& March, 1963). An executive of an innovative trucking company recently recounted to one of the authors an example where top management introduced new SAP business intelligence software that required substantial input from the best engineers. However, because the head of engineering was pressed for productivity and was in particular need of the best engineers, he sent his subpar engineers to SAP development meetings. The result was increased costs in the form of system expenses, system update expenses, consulting expenses, and a subpar intelligence system that was not utilized.

Future research can also concentrate on the ways in which firms recover from mismatch situations. To escape a knowledge overreliance situation, organizations may need to make investments in actively dissolving capabilities or in building a platform of options (Martin de Holan \& Phillips, 2004). Through dissolving obsolete capabilities, firms can regain the flexibility to make smarter investments in knowledge capabilities that better match knowledge requirements (George, 2005). Alternatively, by investing in multiple capabilities and building a platform of options, managerial myopia is minimized and flexibility for future investment increased. To recuperate from a knowledge deficit situation, decision makers will need to stress knowledge investments in order to enhance knowledge acquisition and transfer. In general, recovering from knowledge mismatches requires better understanding how decision makers can change their deep-rooted interpretive schemes of knowledge requirements and knowledge capabilities.

In our theorizing we have assumed the importance of arriving at a match between knowledge requirements and knowledge capabilities. We have not addressed the role of timing and chance in this process. Firms that delay arriving at a match may occasionally be better off. Burgelman (1994) explained that strategic neglect may in some instances be fortuitously beneficial. However, such neglect can just as easily 
lead to misfortune. While the roles of timing and chance fall outside the scope of the theory we have put forth in this paper, we call for future research to explore these factors further.

We have also limited the scope of this paper to knowledge requirements faced by single business units. Our theory does not directly consider the multidivisional organization. However, future theorizing can address the knowledge requirements in the context of multidivisional organizational structures. For example, it will be important to consider how top management teams of multidivisional organizations manage knowledge requirements across divisions and what role cross-divisional synergies play in arriving at matches or mismatches between knowledge requirements and capabilities.

Future research may also examine the linkages between investing in knowledge acquisition and transfer capabilities and the creation of new knowledge. For example, through knowledge acquisition and transfer, organizations can combine or refine existing knowledge (Argote, 1999) or can create new applications for existing knowledge (Kogut \& Zander, 1992; Smith, Collins, \& Clark, 2005). Likewise, creative new insights and ideas may be developed when acquired knowledge is combined with existing knowledge (Cohen \& Levinthal, 1990). We have focused on investments in knowledge capabilities to respond to an organization's need to resolve uncertainty and equivocality instilled by the knowledge requirements it faces. However, through developing these knowledge capabilities, new knowledge may be created that alters the firm's situation or future knowledge requirements (Daft \& Weick, 1984). A promising area of future research is to examine the nature of these linkages among knowledge acquisition, transfer and creation, and knowledge requirements.

In conclusion, viewing organizations as knowledge-dependent interpretation systems helps clarify why knowledge investments are likely to vary widely across organizations and when they will have positive or negative effects on value creation. Some organizations may invest more than others because they face more intense knowledge requirements and would benefit from knowing more. Other organizations may invest more because they hold rosy views of knowledge investments. Both research and practice will benefit from understanding the conditions under which organizations need knowledge, as well as the forces that may contribute to under- or overinvestment in knowledge.

In essence, we challenge the implicit assumption in much extant research (prominent exceptions are Haas \& Hansen, 2005, and Kor \& Leblebici, 2005) and practice that more knowledge is always better. Instead, our theorizing suggests it would be more prudent for organizations to manage their knowledge investments carefully in response to the knowledge requirements they face. If knowledge is central to understanding why organizations exist (Conner \& Prahalad, 1996; Kogut \& Zander, 1992, 1993), then furthering our understanding of why some organizations make certain types of knowledge investments more than others and when these investments lead to value creation is a useful aim. We hope our model helps organize the discourse and research needed in answering this important question.

\section{REFERENCES}

Abrahamson, E., \& Fombrun, C. J. 1994. Macrocultures: Determinants and consequences. Academy of Management Review, 19: 728-755.

Ahuja, G., Coff, R. W., \& Lee, P. M. 2005. Managerial foresight and attempted rent appropriation: Insider trading on knowledge of imminent breakthroughs. Strategic Management Journal, 26: 791-808.

Ahuja, G., \& Katila, R. 2004. Where do resources come from? The role of idiosyncratic situations. Strategic Management Journal, 25: 887-907.

Alavi, M., \& Leidner, D. 2001. Knowledge management and knowledge management systems: Conceptual foundations and research issues. Management Information Systems Quarterly, 25: 107-136.

Aldrich, H. 1979. Organizations and environments. Englewood Cliffs, NJ: Prentice-Hall.

Amis, J., Slack, T., \& Hinings, C. R. 2004. The pace, sequence, and linearity of radical change. Academy of Management Journal, 47: 15-39.

Argote, L. 1999. Organizational learning: Creating, retaining and transferring knowledge. Boston: Kluwer Academic.

Argote, L., McEvily, B., \& Reagans, R. 2003. Managing knowledge in organizations: An integrative framework and review of emerging themes. Management Science, 49: 571-582.

Argyris, N. S. 1999. The impact of information technology on coordination: Evidence from the B-2 "Stealth" bomber. Organization Science, 10: 162-180.

Baker, T., \& Nelson, R. E. 2005. Creating something from nothing: Resource construction through entrepreneurial bricolage. Administrative Science Quarterly, 50: 329366. 
Björkman, I., Barner-Rasmussen, W., \& Li, L. 2004. Managing knowledge transfer in MNCs: The impact of headquarters control mechanisms. Journal of International Business Studies, 35: 443-455.

Bresman, H., Birkinshaw, J. M., \& Nobel, R. 1999. Knowledge transfer in international acquisitions. Journal of International Business Studies, 30: 439-462.

Brown, J. S., \& Duguid, P. 1991. Organizational learning and communities of practice: Toward a unified view of working, learning, and innovation. Organization Science, 2: 40-57.

Brown, S. L., \& Eisenhardt, K. M. 1997. The art of continuous change: Linking complexity theory and time-paced evolution in relentlessly shifting organizations. Administrative Science Quarterly, 42: 1-34.

Burgelman, R. A. 1994. Fading memories: A process theory of strategic business exit in dynamic environments. Administrative Science Quarterly, 39: 24-56.

Coff, R. W. 1999. How buyers cope with uncertainty when acquiring firms in knowledge-intensive industries: Caveat emptor. Organization Science, 10: 144-161.

Cohen, W. M., \& Levinthal, D. A. 1989. Innovation and learning: The two faces of R\&D. Economic Journal, 99: 569-596.

Cohen, W. M., \& Levinthal, D. A. 1990. Absorptive capacity: A new perspective on learning and innovation. Administrative Science Quarterly, 35: 128-153.

Conner, K. R., \& Prahalad, C. K. 1996. A resource-based theory of the firm: Knowledge versus opportunism. Organization Science, 7: 477-501.

Cook, S. D., \& Brown, J. S. 1999. Bridging epistemologies: The generative dance between organizational knowledge and organizational knowing. Organization Science, 10: 381-400.

Cyert, R. M., \& March, J. G. 1963. A behavioral theory of the firm. Englewood Cliffs, NJ: Prentice-Hall.

Daft, R. L., \& Lengel, R. H. 1986. Organizational information requirements, media richness and structural design. Management Science, 32: 554-571.

Daft, R. L., \& Weick, K. E. 1984. Toward a model of organizations as interpretation systems. Academy of Management Review, 9: 284-295.

Davis, J. P., Eisenhardt, K. M., \& Bingham, C. B. 2008. Complexity theory, market dynamism, and the strategy of simple rules. Working paper, Stanford Technology Ventures Program.

Dess, G. G., \& Beard, D. W. 1984. Dimensions of organizational task environments. Administrative Science Quarterly, 29: 52-73.

Dierickx, I., \& Cool, K. 1989. Asset stock accumulation and sustainability of competitive advantage. Management Science, 35: 1504-1515.

DiMaggio, P. J., \& Powell, W. W. 1983. The iron cage revisited: Institutional isomorphism and collective rationality in organizational fields. American Sociological Review, 48: 147-160.

Duncan, R. B. 1972. Characteristics of organizational envi- ronments and perceived environmental uncertainty. Administrative Science Quarterly, 17: 313-327.

Eisenhardt, K. M., \& Santos, F. M. 2002. Knowledge-based view: A new theory of strategy. In A. Pettigrew, H. Thomas, \& R. Whittington (Eds.), Handbook of strategy and management: 139-164. Thousand Oaks, CA: Sage.

Foss, N. J. 2003. Selective intervention and internal hybrids: Interpreting and learning from the rise and decline of the Oticon spaghetti organization. Organization Science, 14: 331-349.

Freiberg, J., \& Freiberg, K. 1996. Is this company completely nuts? Executive Excellence, 13(9): 20

Galbraith, C. S. 1973. Designing complex organizations. Reading, MA: Addison-Wesley.

Galbraith, J. R. 1977. Organization design. Reading, MA: Addison-Wesley.

Gavetti, G., \& Levinthal, D. A. 2000. Looking forward and looking backward: Cognitive and experiential search. Administrative Science Quarterly, 45: 113-137.

George, G. 2005. Learning to be capable: Patenting and licensing at the Wisconsin Alumni Research Foundation 1925-2002. Industrial and Corporate Change, 14: 119-151.

Ghoshal, S., \& Bartlett, C. A. 1990. The multinational corporation as an interorganizational network. Academy of Management Review, 15: 603-625.

Ghoshal, S., Korine, H., \& Szulanski, G. 1994. Interunit communication in multinational corporations. Management Science, 40: 96-110.

Gilbert, C. G. 2005. Unbundling the structure of inertia: Resource versus routine rigidity. Academy of Management Journal, 48: 741-763.

Grant, R. M. 1996a. Prospering in dynamically-competitive environments: Organizational capability as knowledge integration. Organization Science, 7: 375-387.

Grant, R. M. 1996b. Toward a knowledge-based theory of the firm. Strategic Management Journal, 17(Winter Special Issue): 109-122.

Gupta, A. K., \& Govindarajan, V. 2000. Knowledge flows within multinational corporations. Strategic Management Journal, 21: 473-496.

Haas, M. R. 2006. Knowledge gathering, team capabilities, and project performance in challenging work environments. Management Science, 52: 1170-1184.

Haas, M. R., \& Hansen, M. T. 2005. When using knowledge can hurt performance: The value of organizational capabilities in a management consulting company. Strategic Management Journal, 26: 1-24.

Hambrick, D. C., \& Abrahamson, E. 1995. Assessing managerial discretion across industries: A multimethod approach. Academy of Management Journal, 38: 1427-1441.

Hamel, G. 1991. Competition for competence and interpartner learning within international strategic alliances. Strategic Management Journal, 12: 83-103.

Hansen, M. T. 1999. The search-transfer problem: The role of weak ties in sharing knowledge across organization subunits. Administrative Science Quarterly, 44: 82-112. 
Hansen, M. T., \& Haas, M. R. 2001. Competing for attention in knowledge markets: Electronic document dissemination in a management consulting company. Administrative Science Quarterly, 46: 1-28.

Hayek, F. A. 1945. The use of knowledge in society. American Economic Review, 35: 521-530.

Helfat, C. E., \& Peteraf, M. A. 2003. The dynamic resourcebased view: Capability lifecycles. Strategic Management Journal, 24: 997-1010.

Hinings, C. R., \& Greenwood, R. 1988. The dynamics of strategic change. Oxford: Blackwell.

Hoopes, D. G., \& Postrel, S. 1999. Shared knowledge, "glitches," and product development performance. Strategic Management Journal, 20: 837-865.

Inkpen, A. C., \& Dinur, A. 1998. Knowledge management processes and international joint ventures. Organization Science, 9: 454-468.

Jacobson, A., \& Prusak, L. 2006. The cost of knowledge. Harvard Business Review, 84(11): 34.

Jansen, J. J. P., Van den Bosch, F. A. J., \& Volberda, H. W. 2005. Managing potential and realized absorptive capacity: How do organizational antecedents matter? Academy of Management Journal, 48: 999-1015.

Kim, K. K., Umanath, N. S., \& Kim, B. H. 2006. An assessment of electronic information transfer in B2B supply-channel relationships. Journal of Management Information Systems, 22: 293-320.

King, A., \& Ranft, A. L. 2001. Capturing knowledge and knowing through improvisation: What managers can learn from the thoracic surgery board certification process. Journal of Management, 27: 255-277.

King, A. A., \& Tucci, C. L. 2002. Incumbent entry into new market niches: The role of experience and managerial choice in the creation of dynamic capabilities. Management Science, 48: 171-186.

King, A. W., \& Zeithaml, C. P. 2001. Competencies and firm performance: Examining the causal ambiguity paradox. Strategic Management Journal, 22: 75-99.

King, A. W., \& Zeithaml, C. P. 2003. Measuring organizational knowledge: A conceptual and methodological framework. Strategic Management Journal, 24: 763-772.

Kjærgaard, A., \& Kautz, K. 2008. A process model of establishing knowledge management: Insights from a longitudinal field study. Omega, 36: 282-297.

Kogut, B., \& Zander, U. 1992. Knowledge of the firm, combinative capabilities, and the replication of technology. Organization Science, 3: 383-397.

Kogut, B., \& Zander, U. 1993. Knowledge of the firm and the evolutionary theory of the multinational corporation. Journal of International Business Studies, 24: 625-645.

Kor, Y., \& Leblebici, H. 2005. How do interdependencies among human-capital deployment, development, and diversification strategies affect firms' financial performance? Strategic Management Journal, 26: 967-985.

Kriauciunas, A., \& Kale, P. 2006. The impact of socialist imprinting and search on resource change: A study of firms in Lithuania. Strategic Management Journal, 27: 659-679.

Lane, P. J., Koka, B. R., \& Pathak, S. 2006. The reification of absorptive capacity: A critical review and rejuvenation of the construct. Academy of Management Review, 31: 833-863.

Lapointe, L., \& Rivard, S. 2007. A triple take on information system implementation. Organization Science, 18: 89-107.

Leonard-Barton, D. 1992. Core capabilities and core rigidities: A paradox in managing new product development. Strategic Management Journal, 13: 111-125.

Levinthal, D. A., \& March, J. G. 1993. The myopia of learning. Strategic Management Journal, 14: 95-112.

Levitt, B., \& March, J. G. 1988. Organizational learning. Annual Review of Sociology, 14: 319-340.

Lord, M. D., \& Ranft, A. L. 2000. Organizational learning about new international markets: Exploring the internal transfer of local market knowledge. Journal of International Business Studies, 31: 573-589.

March, J. G. 1991. Exploration and exploitation in organizational learning. Organization Science, 2: 71-87.

March, J. G., \& Simon, H. 1958. Organizations. New York: Wiley.

Martin de Holan, P., \& Phillips, N. 2004. Remembrance of things past? The dynamics of organizational forgetting. Management Science, 50: 1603-1613.

McKinley, W., Zhao, J., \& Rust, K. G. 2000. A sociocognitive interpretation of organizational downsizing. Academy of Management Review, 25: 227-243.

Meyer, J. W., \& Rowan, B. 1977. Institutionalized organizations: Formal structure as myth and ceremony. American Journal of Sociology, 83: 340-363.

Miller, D., \& Shamsie, J. 1996. The resource-based view of the firm in two environments: The Hollywood film studios from 1936 to 1965. Academy of Management Journal, 39: 519-543.

Nachum, L., \& Zaheer, S. 2005. The persistence of distance? The impact of technology on MNE motivations for foreign investment. Strategic Management Journal, 26: 747-767.

Nag, R., Corley, K. G., \& Gioia, D. A. 2007. The intersection of organizational identity, knowledge, and practice: Attempting strategic change via knowledge grafting. Academy of Management Journal, 50: 821-847.

Nidumolu, S. R., Subramani, M., \& Aldrich, A. 2001. Situated learning and the situated knowledge web: Exploring the ground beneath knowledge management. Journal of Management Information Systems, 18: 115-150.

Nonaka, I. 1994. A dynamic theory of organizational knowledge creation. Organization Science, 5: 14-37.

Perrow, C. 1967. A fromework for the comparative andlysis of organizations. American Sociological Review, 25: 194-208.

Perrow, C. 1984. Normal accidents: Living with high-risk technologies. New York: Basic Books.

Pettigrew, A. M. 1973. Politics of organizational decision making. London: Tavistock.

Polanyi, M. 1967. The tacit dimension. London: Routledge \& Kegan Paul. 
Raff, D. M. G. 2000. Superstores and the evolution of firm capabilities in American bookselling. Strategic Management Journal, 21: 1043-1059.

Ranft, A. L., \& Lord, M. D. 2002. Acquiring new technologies and capabilities: A grounded model of acquisition implementation. Organization Science, 13: 420-441.

Rosner, M. M. 1968. Economic determinants of organizational innovation. Administrative Science Quarterly, 12: 614-625.

Sabherwal, R., \& Sabherwal, S. 2007. How do knowledge management annoucements affect firm value? A study of firms pursuing different business strategies. IEEE Transactions on Engineering Management, 54: 409-422.

Schweizer, L. 2005. Organizational integration of acquired biotechnology companies into pharmaceutical companies: The need for a hybrid approach. Academy of Management Journal, 48: 1051-1074.

Selznick, P. 1984. Leadership in administration: A sociological interpretation (2nd ed.). Berkeley: University of California Press.

Senge, P. M. 1990. The fifth discipline: The art and practice of the learning organization. New York: Doubleday.

Simon, H. 1957. Administrative behavior (4th ed.). New York: Macmillan.

Smith, K. G., Collins, C. J., \& Clark, K. D. 2005. Existing knowledge, knowledge creation capability, and the rate of new product introduction in high-technology firms. Academy of Management Journal, 48: 346-357.

Spender, J. C. 2003. Exploring uncertainty and emotion in the knowledge-based view of the firm. Information Technology and People, 16: 266-288.

Szulanski, G. 1996. Exploring internal stickiness: Impediments to the transfer of best practice within the firm. Strategic Management Journal, 17: 27-43.

Teece, D. J. 1977. Technology transfer by multinational firms: The resource cost of transferring technological knowhow. Economic Journal, 87: 242-261.
Thomas, A. B., Clark, S. M., \& Gioia, D. A. 1993. Strategic sensemaking and organizational performance: Linkages among scanning, interpretation, action, and outcomes. Academy of Management Journal, 36: 239-270.

Thompson, J. D. 1967. Organizations in action. New York: McGraw-Hill.

Todorova, G., \& Durisin, B. 2007. Absorptive capacity: Valuing a reconceptualization. Academy of Management Review, 32: 774-786.

Vaast, E., \& Levina, N. 2006. Multiple faces of codification: Organizational redesign in an IT organization. Organization Science, 17: 190-201.

Wadhwa, A., \& Kotha, S. 2006. Knowledge creation through external venturing: Evidence from the telecomunications equipment manufacturing industry. Academy of Management Journal, 49: 819-835.

Weick, K. E. 1969. The social psychology of organizing. Reading, MA: Addison-Wesley.

Weick, K. E. 1979. The social psychology of organizing. Reading, MA: Addison-Wesley.

Weick, K. E. 1995. Sensemaking in organizations. Thousand Oaks, CA: Sage.

Winter, S. G. 1987. Knowledge and competence as strategic assets. In D. J. Teece (Ed.), The competitive challenge: Strategies for industrial innovation and renewal. New York: Harper \& Row.

Zahra, S. A., \& George, G. 2002. Absorptive capacity: A review, reconceptualization, and extension. Academy of Management Review, 27: 185-203.

Zander, U., \& Kogut, B. 1995. Knowledge and the speed of the transfer and imitation of organizational capabilities: An empirical test. Organization Science, 6: 76-92.

Zollo, M., \& Winter, S. G. 2002. Deliberate learning and the evolution of dynamic capabilities. Organization Science, 13: 339-351.

Taco H. Reus (treus@rsm.nl) is an assistant professor in the Business-Society Management Department at the Rotterdam School of Business, Erasmus University. $\mathrm{He}$ received his Ph.D. from Florida State University. His research focuses on the boundaries of knowledge-based perspectives and the context and integration processes of mergers and acquisitions.

Annette L. Ranft (aranft@fsu.edu) is the Jim Moran Associate Professor of Management and department chair at Florida State University. She received her Ph.D. from the University of North Carolina at Chapel Hill. Her research interests are in merger and acquisition integration, knowledge-based perspectives, strategic leadership, and corporate governance.

Bruce T. Lamont (blamont@fsu.edu) is the DeSantis Professor of Business Administration and associate dean of graduate programs at Florida State University. He received his Ph.D. from the University of North Carolina at Chapel Hill. His research is in the effective management of large-scale strategic change, strategic leadership, and curious applications of organization theory.

Garry L. Adams (adamsgl@auburn.edu) is an assistant professor in the Management Department at Auburn University. He received his Ph.D. from Florida State University. His research interests include corporate governance, power and politics, organizational learning and resource management, and merger and acquisition integration processes. 
Copyright of Academy of Management Review is the property of Academy of Management and its content may not be copied or emailed to multiple sites or posted to a listserv without the copyright holder's express written permission. However, users may print, download, or email articles for individual use. 